CHILDREN AND THE POLITICS OF CULTURE 
$\begin{array}{lllllll}\text { E } & \mathbf{D} & \mathbf{I} & \mathbf{T} & \mathbf{O} & \mathbf{R} & \mathbf{S}\end{array}$

Sherry B. Ortner, Nicholas B.Dirks, Geoff Eley

A LIST OF TITLES

IN THIS SERIES APPEARS

AT THE BACK OF

THE BOOK 


\section{CHILDREN AND THE POLITICS OF CULTURE}

Sharon Stephens, Editor 
Copyright $\odot 1995$ by Princeton University Press

Published by Princeton University Press, 41 William Street,

Princeton, New Jersey 08540

In the United Kingdom: Princeton University Press, Chichester, West Sussex

All Rights Reserved.

\section{Library of Congress Cataloging-in-Publication Data}

Children and the politics of culture / Sharon Stephens, editor.

p. cm.-(Princeton studies in culture/power/history)

"This collection of papers developed from the session 'Children and the Politics of Culture' organized in connection with the international conference 'Children at Risk' held in Bergen, Norway, in May 1992 and sponsored by the Norwegian Centre for Child Research"-Pref.

Includes bibliographical references and index.

ISBN 0-691-04329-9 (alk. paper).

ISBN 0-691-04328-0 (pbk. : alk. paper)

1. Children-Social conditions. 2. Children-Government policy.

3. Children's rights. 4. Ethnicity in children. 5. Identity (Psychol-

ogy) in children. I. Stephens, Sharon, 1952- . II. Series.

$$
\text { HQ767.9.C449 } 1995
$$

305.23-dc20 95-10602 CIP

Marilyn Ivy, "Have You Seen Me? Recovering the Inner Child in Late Twentieth-Century America," Social Text, 37, pp. 227-52. Copyright

Duke University Press, 1993. Reprinted with Permission.

This book has been composed in Galliard

Princeton University Press books are printed on acid-free paper and meet the guidelines for permanence and durability of the Committee on Production Guidelines for Book Longevity of the Council on Library Resources

Printed in the United States of America by Princeton Academic Press

$$
\begin{array}{rrrrrrrrrr}
1 & 3 & 5 & 7 & 9 & 10 & 8 & 6 & 4 & 2 \\
1 & 3 & 5 & 7 & 9 & 10 & 8 & 6 & 4 & 2 \\
& & & & & \text { (pbk.) } & & & &
\end{array}
$$

